\title{
Generation of Bio-electricity by Microbial Fuel Cells
}

\author{
Maksudur R. Khan ${ }^{1,2}$, M. R. $\operatorname{Karim}^{1}$, M. S. A. Amin ${ }^{1}$ \\ ${ }^{1}$ Department of Chemical Engineering and Polymer Science \\ Shahjalal University of Science and Technology, Sylhet-3114, Bangladesh \\ ${ }^{2}$ Faculty of Chemical and Natural Resources Engineering \\ University Malaysia Pahang, 26300 Gambang, Pahang Malaysia \\ E-mails: mrkhancep@yahoo.com; saikat_cep@yahoo.com
}

\begin{abstract}
Renewable energy is an increasing need in our society. Microbial fuel cell (MFC) technology represents a new technology for the regeneration of electricity from what would otherwise be considered waste and can be a vital candidate for energy in this respect. Electricity directly generated by using bacteria while accomplishing wastewater treatment in MFC processes. The present study deals with performance of proton exchange membrane and cation exchange resin for ion transfer. The effect of dimension of Resin Bridge on electricity generation and COD removal was reported. A maximum voltage of $10.5 \mathrm{mV}$ was observed at 400ppm of $\mathrm{KMnO}_{4}$ along with $400 \mathrm{ml}$ of dairy in an anode chamber. Average COD removal was in the range of $70 \%$ to $90 \%$.
\end{abstract}

Keywords: Microbial fuel cells (MFC); Dairy waste; Voltage; Power density; Current density; cation exchange resin.

\section{Introduction}

Day by day, gradual industrialization and urbanization leading more production of waste material and exposing it to the environment. Microbial fuel cell (MFC) can be a suitable solution to this problem. A MFC is a device that converts chemical energy to electrical energy with the aid of the catalytic reaction of microorganisms [1-2]. MFC generates electricity directly from various biodegradable substrates through microbial release of electrons to an electrode. Microbial fuel cells can be used to recover energy from wastewater while eliminating the need for wastewater 
aeration and reducing sludge production [3-4]. Several types of wastewater have been examined in such process including food processing, municipal, brewery, animal and paper recycling wastewaters [5-6].

An MFC consists of anode and cathode equipped with a suitable ion exchange media (such as membrane, resin. etc.) [7]. The anode chamber is inoculated with microbial colloni. Bacteria gain energy by transferring electrons from an electron donor, such as glucose or acetate, to an electron acceptor, such as oxygen. The larger the difference in potential between donor and acceptor, the larger the energetic gain for the bacterium, and generally the higher the growth yield. In a microbial fuel cell (MFC), bacteria do not directly transfer their electrons to their characteristic terminal electron acceptor, but these electrons are diverted towards an electrode, i.e. an anode. The electrons are subsequently conducted over a resistance or power user towards a cathode and thus, bacterial energy is directly converted to electrical energy [8-10].

In this study attempts were made to develop a membrane-less MFC with using a cation exchange resin and comparative study with the ion exchange membrane.

\section{Experimental}

\section{1 Cell feed:}

The fuel for the cell used was The waste water from dairy [Fulkoli,BISIC,Khadim, Sylhet] and selected on the basis that it was not sterilised .The average nutrient content of the manure was $6 \mathrm{mg} \mathrm{N}, 3 \mathrm{mg} \mathrm{P}, 6.5 \mathrm{mg}$ $\mathrm{K}, 2.5 \mathrm{mg} \mathrm{S}$ and $1.5 \mathrm{mg} \mathrm{Mg} \mathrm{g-1} \mathrm{(manufacturer's} \mathrm{data).} \mathrm{The} \mathrm{measured} \mathrm{calorific}$ value of the manure was $82 \mathrm{~kJ}$ g-1.It was collected and kept in air tight container for 10 days. Then the liquid from it was used as microbial source in the MFC in anode chamber.

\subsection{Cell reactor design:}

The fuel cell reactor was tested as a batch system, similar to a battery. The reactor was constructed in the laboratory using available local PET bottle. Total volume of both anode and cathode compartment was the same $(0.5 \mathrm{~L})$ and each chamber was provided with sample port, wire point inputs (top), inlet and outlet ports as shown in Figure 1.The microbial cells were introduced on the anode chamber of the reactor, in which was located the anode. 


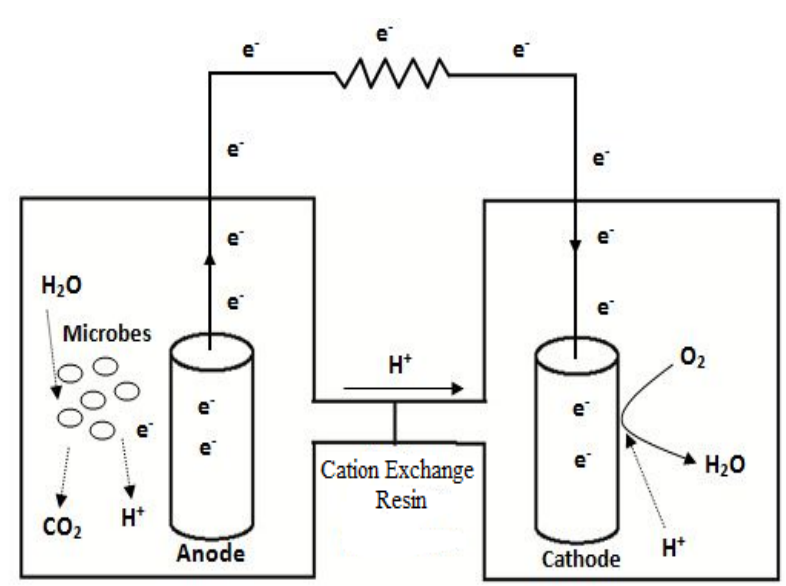

Fig. 1. Construction of MFC

The reactor also equipped with a tubular contact by a packed bed of cation exchange resin for the transfer of $\mathrm{H}+$. The resin beds were constructed from hard plastic tubing, with different internal diameter \& length. Both anode and cathode electrodes were made of graphite rod obtained from local dry cell factory and were positioned at a distance of $2 \mathrm{~cm}$ on either side of the membrane. Each electrode had a surface area of $25.635 \mathrm{sq}$. $\mathrm{cm}$ (both anode and cathode). Prior to use, the electrodes were soaked in de-ionized water for a period of $24 \mathrm{~h}$. Contact between electrodes and copper wires was sealed with epoxy material. MFC was operated in batch mode at room temperature $\left(28 \pm 2{ }^{\circ} \mathrm{C}\right)$.

\subsection{Analytics and calculations}

Current and voltage were recorded with a fixed resistance by a precise digital multimeter (FL-9205A, SHEN-ZHENXL Electronic Co. Ltd, China). Power was calculated from the relation of $\mathrm{P}=\mathrm{IV}$, where, I and $\mathrm{V}$ represents current $(\mathrm{A})$ and voltage $(\mathrm{V})$, respectively. Power and current density were calculating by dividing the obtained power and current by the anode surface area (m2). Decolorization, $\mathrm{COD}$ and $\mathrm{pH}$ were monitored in the anodic chamber of MFC during operation.

\section{Result and Discussions}

\subsection{Performance of proton exchange membrane and resin based MFC}

To scrutinize the performance between PEM and cation exchange Resin for ion transfer media in different MFCs were operated. Both MFC used same waste water in anode chamber and same quantity of $\mathrm{KMnO} 4$ in cathode chamber. 
Figure 2 we observe the performance of current generation between proton exchange membrane and cation exchange resin.

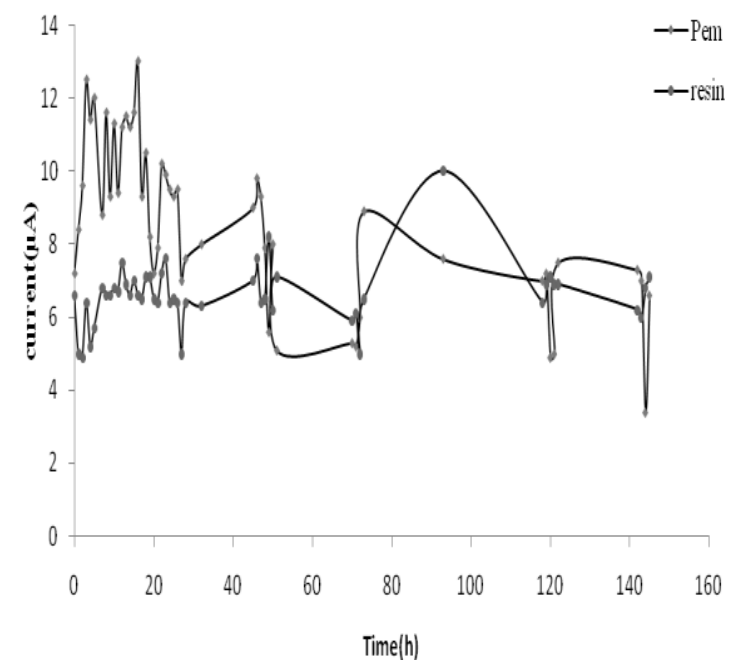

Fig. 2. Comparison between current generated by PEM \& Resin based MFC

Figure displayed that the generation of current with respect to time via PEM and Rasin. The figure shows that the initial current given by PEM is higher and gradually decreases where that for the resin is approximately steady at initial state with increment at higher time.

\section{2 Effect of length of resin bed with constant diameter}

To know the effect of cation exchange bed length three MFC used which length was $5.5 \mathrm{~cm}, 3.7 \mathrm{~cm}$ and $2.5 \mathrm{~cm}$ respectively with constant diameter. Figure 3 shows the current generation is increased for greater bed length on the on the other hand lower bed length shown lower current. 


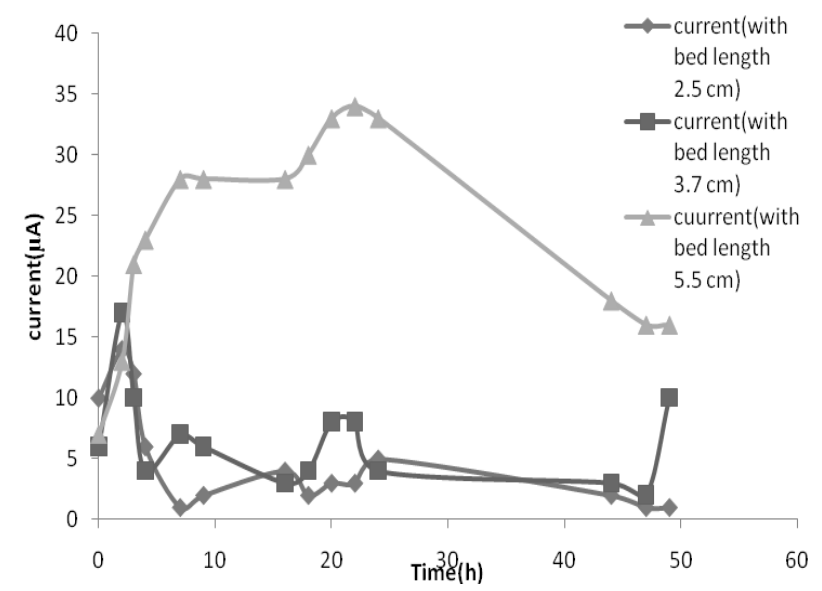

Fig. 3. current generation data of different bed length with constant diameter( when $400 \mathrm{ml}$ dairy waste water in anode and $400 \mathrm{ppm}$ of $\mathrm{KMnO}_{4}$ in cathode at the room temperature over 49 hours operation and current measured using $10 \Omega$ resistance)

\subsection{COD removal}

A COD removal of in the range of $70 \%$ to $89 \%$ for the cells containing 300, 400 $\mathrm{mL}$ of waste water with $400 \mathrm{ppm}, 500 \mathrm{ppm} \mathrm{KMnO} 4$ in cathode chamber. So, the removal of COD is found to be higher for the cell which showed higher current production.

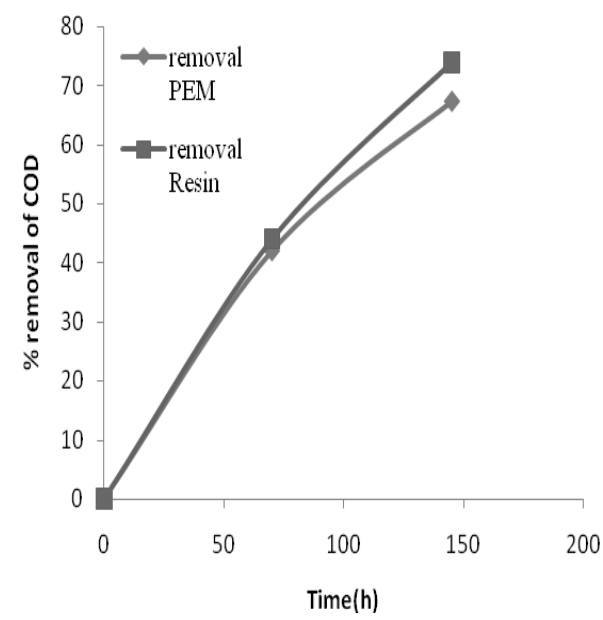

Fig. 4. Percent removal of COD in terms of time (When $400 \mathrm{ml}$ waste water in anode and $400 \mathrm{ppm}$ of $\mathrm{KMnO}_{4}$ maintained in cathode at room temperature over 145 hrs. operation) 


\section{4 Power curve for different bed diameter}

The polarization curve characterizes the cell voltage as a function of current. The current, in turn, depends on the size of the electrical load placed across the fuel cell. In essence the polarization curve shows the electrochemical efficiency of the fuel cell at any operating current.

At first, the power densities showed an incremental trend with increasing external resistance. But after reaching a peak value, the power densities begin to fall down with increasing resistance and current density. Current generation showed decreasing trend with increase in resistance and is consistent with the reported literature [11], which indicated a typical fuel cell behavior.

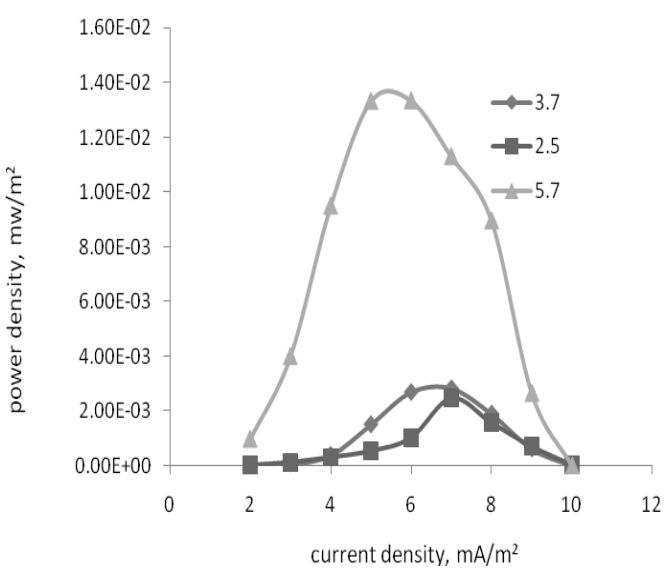

Fig. 5. Power density vs. current density curve for three MFCs using variable resin length

\section{Conclusion}

In this study the performance of cation exchange resin instead of proton exchange membrane as an ion transfer media for microbial fuel cell was investigated. It is notable that the price of proton exchange membrane is very much higher and difficult to regenerate than ion exchange resin. Also the macro porous nature of the resin used in these study facilities the ion exchange kinetics. Microbial Fuel cell was fabricated and constructed with local markets materials. It has been observed that the current generation of a MFC increased for higher cross-sectional area of resin bed. Concentration polarization was found to be negligible. Some affect of activation polarization was observed. The removal of COD is found to be higher for the cell which showed higher current density. The highest COD removal was found $90.65 \% \%$ for the cell containing $3.7 \mathrm{~cm}$ bed length with $400 \mathrm{ml}$ dairy waste water in anode chamber and 400ppm $\mathrm{KMnO} 4$ in cathode 
chamber. Also maximum power density was recorded as $1.616 \mathrm{~mW} / \mathrm{m} 2$ at the current density $.022703 \mathrm{~A} / \mathrm{m} 2$ for the MFC cell containing $400 \mathrm{ml}$ dairy waste water in anode chamber and 400ppm $\mathrm{KMnO} 4$ in cathode chamber with $3.5 \mathrm{~cm}$ bed dia.

\section{References}

[1] Allen, R.M., Bennetto, H.P, (1993). Microbial fuel-cells: electricity production from carbohydrates. Appl. Biochem. Biotechnol, 40:27-40.

[2] Bennetto (1990). Electricity generation by microorganisms. Biotechnology Education, 1(4), 163-168.

[3] Liu, H., Ramnarayanan, R. and Logan, B.E., (2004). Production of electricity during wastewater treatment using a single chamber microbial fuel cell, Environ. Sci. Technol., 38:2281-2285.

[4] Logan, B. E., Hamelers, B., Rozendal, R., Schroder, U., Keller, J., Freguia, S., et al. (2006). Microbial fuel cells: Methodology and technology. Environ Sci Technol, 40, 5181- 5192.

[5] Park, D. H., \& Zeikus, G. (2003). Improved fuel cell and electrode designs for the producing electricity from microbial degradation. Biotechnol. Bioeng., 81, 348-355.

[6] Oh S. and Logan, B.E. (2005). Hydrogen and electricity production from a food processing wastewater using fermentation and microbial fuel cell technologies. Water Res., 39, 4673-4682.

[7] Kim, B.H., Ikeda, T., Park, H.S., Kim, H.J., Hyun, M.S., Kano, K., Takagi, K., Tatsumi H., (1999). Electrochemical activity of an Fe (III)-reducing bacterium, Shewanellaputrefaciens IR-1, in the presence of alternative electron acceptors. Biotechnol. Tech., 13:475-478.

[8] Rao, J. R.; Richter, G. J.; Von Sturm, F.; Weidlich, E., (1976). The performance of glucose electrodes and the characteristics of different biofuel cell constructions. Bioelectrochem. Bioenerg., 3,139-150.

[9] Pant, D., Bogaert, G. V., Diels, L., \& Vanbroekhoven, K. (2010). A review for the substrate used in microbial fuel cell (MFCs) for sustainable energy production. Bioresource Technology, 101(6), 1533-1543.

[10] Rabaey, K., Boon, N., Siciliano, S. D., M, M. V., \& Verstraete, W. (2004). Biofuel cells select for microbial consortia that self-mediate electron transfer. Appl. Environ. Microbiol. , 70(5373-5382).

[11] Mohan, S. V., Saravanan, R., Veer, S. R., Mohanakrishna, G., \& Sarma, P. N. (2006). Bioelectricity production from wastewater treatment in dual chambered microbial fuel cell (MFC) using selectively enriched mixed microflora: Effect of catholyte. Bioresour. Technol., 99(3), 596-560. 